\title{
The Effect of Human Resources, Management and Capital Performance toward Return on Asset Case Study on Islamic Bank 2011-2015
}

\author{
Dian Filianti and Dina Fitrisia Septiarini \\ Islamic Economy Department-Economy and Business Faculty-Airlangga University, Indonesia \\ dianfilianti@feb.unair.ac.id,dinafitrisia@feb.unair.ac.id
}

Keywords: CAR, Good Corporate Governance, iB-VAIC, Intellectual Capital, Islamic Banking, Return on Asset.

\begin{abstract}
The purpose of this study is to determine the effect of intellectual capital partially and simultaneously with iB-VAIC, the quality of GCG implementation, and capital adequacy level towards ROA (a case study Islamic bank during 2011-2015). The results showed that partially intellectual capital with iB-VAIC and capital adequacy level significantly affect the ROA, while the GCG quality do not significantly affect ROA. Simultaneous research results showed that intellectual capital with iB-VAIC, quality of GCG implementation and the capital adequacy level significantly affect ROA. Therefore, the management of intellectual capital or resource management with a good knowledge and quality management of GCG supported by sufficient capital to support the operations of the company will be able to increase the ROA of Islamic banks.
\end{abstract}

\section{INTRODUCTION}

Islamic banks are banks which have different operational from the conventional bank. One of the Islamic bank characteristics is not receiving or burdening their customer with interest, however receiving or burdening profit sharing and other rewards according to the covenant. The concept of Islamic Bank is based on Quran and hadith. All the products and services offered must not be in contradiction with Quran and hadith from Rasulullah SAW (Ismail, 2011: 29).

\subsection{Stakeholder Theory}

In the context of explaining about IC concept, the stakeholder theory must be seen from both sector, either ethics (moral) or managerial sector. The ethics sector argued that every stakeholder has the right to be treated equitably by the organization, also manager must manage the organization for the importance of every stakeholder (Deegan, 2004 in Ulum, 2009: $5 \& 6)$. In the context of a relationship between IC and financial performance, the stakeholder theory is more appropriate as the main basis to explain the relationship of IC and company performance. From the stakeholder theory point of view, the company has stakeholders, not only shareholder (Riahi-Belkaoui, 2003 in Ulum, 2009: 8).

\subsection{Resource-Based Theory}

According to Resource-Based Theory, IC fill the criteria as unique resources to create competitive superiority for the company by creating value added. The value added is in the form of the better performance in the company.

\subsection{Intellectual Capital}

According to Sawarjuwono and Kadir (2003), IC is the amount of what is produced by the three main elements of an organization (human capital, structural capital, customer capital) which is related to knowledge and technology that enables the company to provide more value to a company in the form of organization competitive superiority.

Frequently, the term of intellectual capital is treated as a synonym of intangible assets. Nevertheless, the definition proposed by OECD is quite different by putting intellectual capital as a separate part from the intangible asset basic determination as for the overall company. Therefore, there are items of an intangible asset which logically is not a part of the intellectual capital of the company. 
One of it is company reputation. Company reputation may be the side result (or a consequence) from IC wisely utilization in the company, but it is not a part of intellectual capital (Ulum, 2009: 21).

\section{4 iB-VAIC (Islamic Banking Value Added Intellectual Coefficient)}

On his research, Ulum (2013) formulated IC performance assessment model for Islamic banking which will be named iB-VAIC (Islamic Banking Value Added Intellectual Coefficient) which is important to be generated as a modification of an existing model, VAIC (Value Added Intellectual Coefficient). VAIC is designed to measure the intellectual capital performance of companies with common types of transactions. Meanwhile, Islamic banking has their own type of transactions which are quite different from common or conventional banking. The three formula to calculate iB-VAIC as follows:

The first stage is calculating Islamic Banking Value Added (iB-VA). iB-VA is calculated as the difference between output and input. Output (OUT) is presented as revenue and covers the entire product and services that sale on market, however input (IN) cover all the load used to gain revenue. The most important thing on this method is the labor expenses are not included on IN. As their active role in the value creation process, the intellectual potential (which is represented with labor expenses) is not calculated as cost and not included on IN component.

$$
\text { iB-VA=OUT }- \text { IN }
$$

Notes:

OUT (Output): Total income, obtained from Islamic activity net income $=$ Islamic activity main operation income + other operational income - third parties' right on sharing profit and temporary syirkah funds.

The second stage, calculating Islamic Banking Value Added Capital Employed (iB-VACA). The formula used is:

$$
\mathrm{iB}-\mathrm{VACA}=\frac{\mathrm{iB}-\mathrm{VA}}{\mathrm{CE}}
$$

Notes:

CE: Capital Employee: available funds (total liquidity)

The third stage, calculating Islamic Banking Value-Added Human Capital (iB-VAHU).

$$
\mathrm{iB}-\mathrm{VAHU}=\frac{\mathrm{iB}-\mathrm{VA}}{\mathrm{HC}} .
$$

Notes:

HC: Human capital: labor expenses

The fourth stage, calculating Islamic Banking Structural Capital Value Added (iB-STVA).

$$
\text { iB-STVA }=\frac{S C}{i B-V A}
$$

Notes:

SC: Structural Capital: iB-VA - HC

The fifth stage, calculating iB-VAIC:

$i B-V A I C=i B-V A C A+i B-V A H U+i B-$ STVA.

Kamath in Ulum (2009: 92) classifying bank performance according to the Intellectual Capital into four categories:

Table 1: Category VAIC ${ }^{\mathrm{TM}}$.

\begin{tabular}{|c|l|}
\hline VAIC value & \multicolumn{1}{|c|}{ Category } \\
\hline$>3$ & Top Performers \\
\hline $2.00-2.99$ & Good Performers \\
\hline $1.50-1.99$ & Common Performers \\
\hline$<1.5$ & Bad Performers \\
\hline
\end{tabular}

Source: Ulum (2013)

\subsection{Good Corporate Governance (GCG)}

Bank Indonesia Regulation (PBI) No. $11 / 33 / \mathrm{PBI} / 2009$ defines GCG as a bank governance that applies transparency, accountability, responsibility, professionalism, and fairness.

\subsection{Islamic Corporate Governance}

According to Muneeza and Rusni (2014) the definition of shariah corporate governance or commonly referred to Islamic corporate governance is:

"Shari'ah corporate governance is the Islamic version of corporate governance. This is the simplest way to explain what Shari'ah corporate governance is."

The purpose of definition aforementioned about shari'ah corporate governance is Islamic corporate governance. This is the simplest way to explain what is Shari'ah corporate governance.

\subsection{Islamic Bank Capital Management}

Capital is the most important factor for bank development and improvement also maintain the 
public trust. Every creation of assets, as well as potentially making a profit also potentially causing a risk. Therefore, the capital has to be used to maintain the possibility of risk of loses on assets investment, especially funds from third parties or public (Muhammad, 2004: 210).

\subsection{Bank Capital Adequacy}

Capital adequacy is the most important thing on business banking. Banks who have good capital adequacy level indicates a healthy bank. Because bank capital adequacy indicating its state that represented by a specific ratio called capital adequacy ratio (CAR).

\subsection{Islamic Bank Finance Performance}

On traditional management, the size of performance which often used is finance performance, because it is a easiest factor to measure. Profitability is the most appropriate indicator to measure the bank performance. The size of profitability on banking industry which often used is Return on Assets (ROA) (Rivai, 2009: 686).

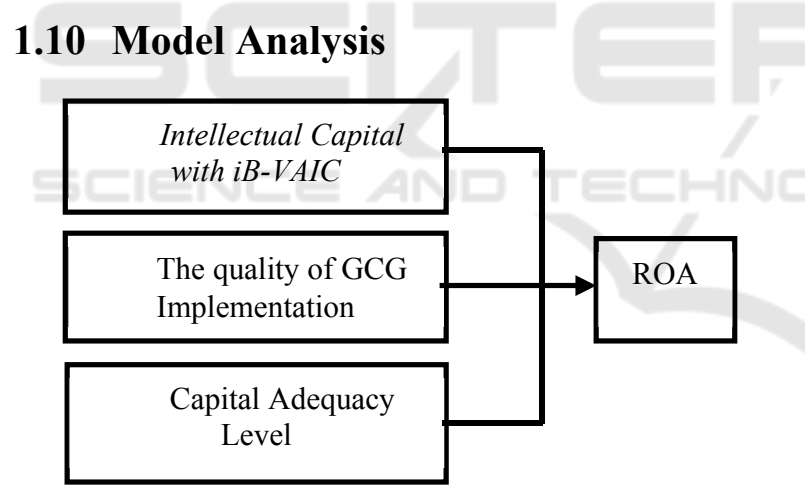

Figure 1: Model Analysis. Source: Various sources, processed.

Based on the explanation above, the regression equation:

$$
\mathrm{Y}=\mathrm{a}+\mathrm{b} 1 \mathrm{X} 1+\mathrm{b} 2 \mathrm{Xz}+\mathrm{b} 3 \mathrm{X} 3
$$

\section{METHODS}

This research was conducted with a quantitative approach where the research data in the form of numbers and analyzed using statistic tool.
According to the hypothesis and model analysis, the variable in this research consists of the dependent variable and independent variable, i.e.:

The independent variable in this research is the intellectual capital with iB-VAIC (X1), GCG Implementation Quality (X2), and capital adequacy level (X3).The dependent variable in this research is Return on Asset (Y).

The types of data used in this study are secondary data. The data comes from an annual report from 2011 to 2015 that have been published on the website of each of the selected banks. The samples are selected using purposive sampling technique. There are 10 selected Islamic banks in total.

After selecting the sample and determining the variables used in this study, the next step that should be done is processing the data using regression analysis to test the hypothesis. To assist the research, the researcher will process the statistical data using software Eviews version 8. The data analysis technique in this research is regression models for panel data analysis. The regression models for panel data analysis is a combination of time series and cross-section data.

According to Wibisono (2005) in Ajija, et al (2011: 51), pooled data is a combination of time series and cross-section data. By accommodating the information either related to the cross-section variables or time series, panel data substantially reduces the omitted-variables problems, which disregards the relevant variable.

According to Ajija, et al (2011:51) there are 3 approaches used to estimate the regression model for panel data, i.e.: Common Effect/Polled Least Square (PLS), Fixed Effect Model (FEM), and Random Effect Model (REM). There are 2 approaches which frequently used to determine the best model for this research, i.e.: Chow test and Hausman test.

\section{RESULTS AND DISCUSSION}

\subsection{Panel Data Estimation Model Selection}

Steps to get the precise model by conducting the Chow Test and Hausman Test 
Table 2: Chow Test.

\begin{tabular}{|l|r|r|r|}
\hline $\begin{array}{l}\text { Effects } \\
\text { Test }\end{array}$ & Statistic & d.f & Prob. \\
\hline $\begin{array}{l}\text { Cross- } \\
\text { section F }\end{array}$ & 9.288185 & $(9,37)$ & 0.0000 \\
\hline $\begin{array}{l}\text { Cross- } \\
\text { section } \\
\text { Chi-square }\end{array}$ & 59.075444 & 9 & 0.0000 \\
\hline
\end{tabular}

Source: Eviews 8.

The probability value (Cross-section F) obtained from Table 2 of 0,0000 which means that probability value (Cross-section F) less than $\alpha(0,05)$ so $\mathrm{H} 0$ is rejected and $\mathrm{H}_{1}$ is accepted.

Table 3: Hausman Test.

\begin{tabular}{|l|r|r|r|}
\hline $\begin{array}{l}\text { Test } \\
\text { Summary }\end{array}$ & $\begin{array}{r}\text { Chi-Sq. } \\
\text { Statistic }\end{array}$ & Chi-Sq. d.f. & Prob. \\
\hline $\begin{array}{l}\text { Cross- } \\
\text { section } \\
\text { random }\end{array}$ & 57.387396 & 3 & 0.0000 \\
\hline
\end{tabular}

The probability value (Cross-section random) obtained according to Table 3 of 0,0000 which less than $\alpha(0,05)$ means that $\mathrm{H}_{0}$ is rejected and $\mathrm{H}_{1}$ is accepted, can be concluded that Fixed Effect Model (FEM) is the best model to use better than Random Effect Model (REM).

Based on the selection result of panel data model above, it can be concluded that the best analysis method to analyze panel data on this result is Fixed Effect Model (FEM). The result from Fixed Effect Model (FEM) can be explained in Table 5.

(FEM) better than Pooled Least Square/Common Effect Model (CEM).

Rejected and $\mathrm{H} 1$ is accepted, it can be concluded that the best temporary model to use is Fixed Effect Model
Table 4: Fixed Effect Model (FEM) Estimation Result.

\begin{tabular}{|c|c|c|c|}
\hline \multicolumn{4}{|c|}{$\begin{array}{l}\text { Dependent Varisble: ROA? } \\
\text { Method: Pooled Least Squares } \\
\text { Date: } 01 / 10 / 17 \text { Time: 08:10 } \\
\text { Semple: } 20112015 \\
\text { Included observatioes: } 5 \\
\text { Cross-sections ineluded } 10 \\
\text { Total pool (balenced) observations: } 50\end{array}$} \\
\hline Variable & Coefficient & Std. Error t-Statistic & Prob. \\
\hline $\begin{array}{c}\text { C } \\
\text { IBVAIC? } \\
\text { GCG? } \\
\text { CAR? } \\
\text { Fixed Effects } \\
\text { (Cross) } \\
\text { BMES-C } \\
\text { BMa-C } \\
\text { BSB-C } \\
\text { BCAS-C } \\
\text { BRIS-C } \\
\text { BNIS-C } \\
\text { BSM-C } \\
\text { BPS-C } \\
\text { BVS-C } \\
\text { BMS-C }\end{array}$ & $\begin{array}{r}0.023100 \\
0.003522 \\
0.013309 \\
0.009388 \\
0.024825 \\
0.017848 \\
0.016306 \\
-0.020098 \\
-0.021825 \\
-0.066375\end{array}$ & $\begin{array}{rr}0.011816 & -6.513911 \\
0.001495 & 14.41653 \\
0.005570 & 1.075683 \\
0.023988 & 3.592959\end{array}$ & $\begin{array}{ll}1 & 0.0000 \\
3 & 0.0000 \\
3 & 0.2890 \\
9 & 0.0009\end{array}$ \\
\hline \multicolumn{4}{|c|}{ Effects Specification } \\
\hline \multicolumn{4}{|c|}{ Cross-section fuxed (dummy variables) } \\
\hline $\begin{array}{l}\text { R-squared } \\
\text { Adjusted R-squared } \\
\text { S.E. of regression } \\
\text { Sum squared resid } \\
\text { Log lakelihood } \\
\text { F-statistic } \\
\text { Prob(P-statistic) }\end{array}$ & $\begin{array}{l}0.902878 \\
0.871379 \\
0.012013 \\
0.005340 \\
157.6671 \\
28.66380 \\
0.000000\end{array}$ & $\begin{array}{l}\text { Mean dependent var } \\
\text { S.D. dependent var } \\
\text { Akaike info criterion } \\
\text { Schwarz eriterion } \\
\text { Hannan-Quinn criter. } \\
\text { Durbin-Watson stat }\end{array}$ & $\begin{array}{l}0.008240 \\
0.033497 \\
-5.786686 \\
-5.289560 \\
-5.597377 \\
2.451218\end{array}$ \\
\hline
\end{tabular}

Based on the estimation result in Table 4, the linear equation can be written as follow:

$\mathrm{ROA}=-0,076970+0,021553 \mathrm{IBVAIC}$

$0,005992 \mathrm{GCG}+0,000862 \mathrm{CAR}$

\subsection{The Effect of Partially Intellectual Capital with iB-VAIC toward Return on Asset of Islamic Bank}

The result showed that intellectual capital variable which is calculated using iB-VAIC partially significant difference toward return on asset of Islamic bank in Indonesia. It can be seen from the probability value (t-statistic) that the number is 0,0000 . The significance value is less than 0,05 so the $\mathrm{H} 01$ is rejected an Hal is accepted and can be concluded that intellectual capital variable with iBVAIC is partially significant difference toward the return on asset of Islamic bank period 2011-2015.

This indicates that intellectual capital with iBVAIC has an important role to improve the return on asset of an Islamic bank. The higher the value of intellectual capital with iB-VAIC (Islamic Banking 
Value Added Intellectualgv Coefficient) of an Islamic bank, the higher it will create a value-added for the bank. Value added is a competitive superiority which able to improve the return on assets of the bank.

This strengthens the stakeholder theory by Ulum (2009: 6), who states that when the manager able to manage the organization maximally, especially in the attempt to create value for the company, it means that manager has been filling the aspect of both ethics and theory. The context of value creation is by utilizing all the company's potential, either employee (human capital), physical capital, or structural capital. The well the management of all this potential, the more it will create value added for a company which able to encourage the company financial performance for the importance of stakeholder. The result of this study also support the resource-based theory that the good resource management will increase the value added of company in order to compete in business industry.

This result supports the research conducted by Ulum (2007) who concluded that intellectual capital positively significant difference toward the company performance now and in the future (ROA, ATO, and GR). This research also support the research conducted by Chen et al. (2005) in Ulum (2009:101) if the utilization of intellectual capital is good, the company profitability will increase so the company performance will be better. Therefore, the company ability to gain profit with the total assets owned will increase if the company able to maximizing the intellectual capital performance.

The knowledge into company's resources are inherent knowledge and owned by each people on the company which able to use to the importance of company. Those knowledge resources are abstract and often called as intangible assets or intellectual capital. Those resources are more potentially provide the competitive superiority than tangible resources (Nasih, 2012). Nowadays in order to facing the competition, knowledge has an important role. As already explained by Quran on surah Ar-Rahman 33:

\section{Yā másyaral-jinni wal-insiinistatá tum an tanfużū min

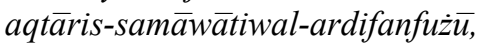 lātanfużūnaillābisultān}

$\mathrm{O}$ jinn and mankind if you are able to pass beyond the regions of heavens and earth, then pass. You will not pass except by authority from Allah (Ministry of Religious Affairs, 2010: 532).

\subsection{The Effect of Partially Good Corporate Governance Implementation toward the Return on Asset of Islamic Bank.}

This result showed that GCG implementation variable calculated from self-assessment result of GCG implementation in the form of composite value is not partially significant difference toward return on assets of Islamic bank in Indonesia. It can be seen from the probability value (t-statistic).

According to the data, it can be seen that the probability level (t-statistic) of 0,2890. That significance value is higher than 0,05 so $\mathrm{H} 01$ is accepted and $\mathrm{Hal}$ is rejected. According to Permatasari and Retno (2014), the GCG composite value had no significant difference on ROA of Islamic bank so it can be concluded that good implementation of the bank did not guarantee the improvement of the bank performance.

This research also supports the research which already conducted by Permatasari and Retno (2014). The research conducted by Permatasari and Retno showed that GCG implementation quality does not affect the bank performance. Meanwhile, this result rejects the research conducted by Tjondro and Wilopo (2011) who stated that GCG had a positive effect toward the profitability of the banking company.

The GCG implementation quality will be better if the GCG composite value is low. It means, the better of bank governance implementation then the better of bank performance. However, the good GCG implementation does not guarantee the bank ROA performance as the result of this research which showed that the quality of GCG implementation does not partially significant difference toward ROA of an Islamic bank.

For instance, Victoria Islamic Bank on 2014 had a composite value of 1,930 and already applied the good GCG implementation. However, the ROA of Victoria Islamic Bank on 2014 suffered loss of 0,0187 . This loss because too cautious in distributing fund so its distribution is not frontal which led to the decline of profit. Furthermore, Victoria Islamic Bank on 205 had a high composite value of 3,000 it means the GCG implementation of Victoria Islamic Bank is quite good. However, the ROA of Victoria Islamic Bank on 2015 suffered loss of $-0,0236$. The decline of ROA because the less of cautious in distributing funds, so a lot of financing problems which led to the decline of profit.

The implementation GCG quality is a company operational activity mechanism to run in accordance 
with the company mechanism. From the research above, the good GCG implementation is not guaranteed to improve the ROA of the bank. The ROA improvement affected by several factors, one of it is profit. If there are a lot of Islamic Bank which is lost during this period also the possibility about other factors and variables that are not examined make this research is not significant.

\subsection{The Effect of Capital Adequacy Level Partially Toward the Return on Assets of Islamic Bank}

The result showed that capital adequacy level variable which is calculated using CAR had partially significant difference toward ROA of Islamic bank in Indonesia. It can be seen from the probability value (t-statistic). According to the data, it can be known that probability level (t-statistic) of 0,0009 . That significance value is higher than 0,05 so $\mathrm{H} 01$ is rejected and $\mathrm{Ha} 1$ is accepted. Therefore, the higher CAR of Islamic bank the higher Bank capital ability to maintain the possibility of business activity loss risk so the ROA of Islamic bank will increase.

This research also supports the research which already conducted by Pasaribu and Rosa (2011). The research result conducted by Pasaribu and Rosa showed that the capital adequacy level by Capital Adequacy Ratio (CAR) was significant difference toward the return on assets. However, it is not accordance with research conducted by Widyaningrum (2015). The research conducted by Widyaningrum showed that CAR was not significant difference toward ROA.

CAR is the most important thing for a bank in order to develop its business and accommodate the loss also reflect the health of bank which aims to maintain the public trust about banking, protect the public funds and to fulfill the Islamic Bank standard.The most important capital factor to run the bank operational activity and for support their needs, with the quality of management to maintain the banking activity to get the expected profit level. With a proper management, the bank will keep increasing their capital and pay attention to capital health indicator, i.e.: CAR, so that the profitability will increase.

In the implementation of a business or good resources management also the good company governance without support from sufficient capital make business will not run properly. Capital is one of the important things on Islamic bank. Without capital, the bank can not to run they're daily operational, the public trust and support their needs.

\subsection{The Influence of Intellectual Capital with iB-VAIC, GCG Implementation, and Capital Adequacy Level Simultaneously toward the Return on Assets of Islamic Bank}

This result showed that intellectual capital with iBVAIC, GCG implementation quality, and capital adequacy level are simultaneously significant difference toward ROA. It can be seen from the probability value (F-statistic). According to the data, it can be known that probability level (F-statistic) of 0,000000 . That significance value is higher than 0,05 so $\mathrm{H} 01$ is rejected and $\mathrm{Ha} 1$ is accepted.

The intellectual capital with iB-VAIC, GCG implementation quality, and capital adequacy level which well and consistently maintained able to improve the return on asset of a company. It showed that intellectual capital which efficiency maintained to indicate that such bank able to well maintain their resources, the well-maintained resources will increase the employee ability so this ability will contribute to enhancing the company performer and the competitive superiority for the company will be achieved.

The company will be able to compete if it has a good management inside it. The GCG implementation quality is a way to actualize the good management of a bank. The big impact of a company performance is the company itself, how the management able to maintain a good company for its main reason. With a good knowledge management and also good quality of management if it is not supported with sufficient capital so the company will not able to run. As capital is the most important thing in the development and improvement of a company. Capital also used to support the daily activities in order to enhance the public trust. With a proper management, the bank will keep increasing their capital and pay attention to capital health indicator, i.e.: CAR, so that the ROA will also increase.

\section{CONCLUSION}

According to the result and the discussion, it can be concluded that:
1. The intellectual capital with iB-VAIC is the partially significant difference to the ROA of Islamic bank period 2011-2015. 
2. The GCG implementation quality variable is not partially significant difference to the ROA on Islamic bank period 2011-2015.

3. The capital adequacy level is the partially significant difference to the ROA on Islamic bank period 2011-2015.

4. This intellectual capital with iB-VAIC, GCG implementation quality, and capital adequacy level are the simultaneously significant difference to the ROA of Islamic bank period 2011-2015.

The suggestion from this research as follows:

1. For Islamic bank

This result can be used as a tool to reform according to the maintaining the knowledge resource, GCG implementation, and capital adequacy level. This result indicates that IC that calculated using iB-VAIC, GGC implementation quality, capital adequacy level, and ROA are connected. It is no doubt that knowledge resource is a lifeblood for the bank to success. The IC existence should be considered in order to create value-added in a company because the result obtained in this research emphasize that intellectual capital is positively connected to the ROA. The good knowledge resource maintenance able to improve the employee ability in implementing GCG so the bank can fill their responsibility to supplying minimum capital. However, if a bank implementing GCG well should be followed by financing improvement in a bank, then improving a profit and consequently improving ROA of the bank.

2. For the next researcher

For the next researcher is able to expand the sample research, increase the number of research period to get the better result, and also use other indicators in terms of Islamic bank performance measurement.

\section{REFERENCES}

Ajija Shochrul R et al. 2011. Smart way to mastering Eviews. Jakarta: SalembaEmpat.

Ismail. 2011. Islamic Banking. First Edition. Jakarta: Kencana.

Ministry of Religious Affairs. 2010. My Quran with Color Block Tajwid with Translation. Jakarta: Lautan Lestari.

Muhammad. 2004. Islamic Bank Management.First Edition. Jogjakarta. Ekonisia.

Muneeza, Aishath and Rusni Hassan. 2014. Shari'aCorporate Governance: The Need for A Special Governance Code. International Journal of Business in Society. Vol. 14 No. 1, pp. 120-129.
Nasih, Moh. 2012. Human as Determinant Creator of Value and Banking Company Performance in Indonesia. Community, Culture, And Politic Journal, Vol. 25 No. 4.

Pasaribu, Hiras, and Rosa Luxita Sari. 2011. The Analysis of Capital Adequacy Level and Loan to Deposit Ratio Toward the Profitability. Study and Accounting Research Journal. Vol. 4 No. 2. Page 114-125.

Permatasari, Ika and Retno Novitasary. 2014. The Effect of Good Corporate Governance Implementation Toward the Capital and Banking Performance in Indonesia: Risk Management as The Intervening Variable. The Application of Quantitative Economics Journal. Vol. 7 No. 1.

Rivai, Veithzal. 2009. Islamic Human Capital from Theory to Practice of Islamic Resources Management. Jakarta: PT Raja GrafindoPersada.

Sawarjuwono, Tjiptohadi and Agustine Prihatin Kadir 2003. Intellectual Capital, Treatment, Measurement, and Report (A Library Research). Accounting and Financial Journal. Vol. 5, No.1. May 35-57.

Tjondro, David and R. Wilopo. 2011. The Effect of Good Corporate Governance (GCG) Toward the Profitability and Banking Stock Performance that Recorded in Indonesia Stock Exchange. Journal of Business and Banking. Vol 1, No 1.page 1-14.

Ulum, Ihyaul 2007. The Effect of Intellectual Capital Toward the Banking Financial Performance in Indonesia. Publication Thesis. Semarang: Diponegoro University Post Graduate Program.

Ulum, Ihyaul. 2009. Intellectual Capital: Concept and Empirical Study. Jogjakarta. Graha Ilmu.

Ulum, Ihyaul. 2013. "iB-VAIC: The Model of Islamic Banking Intellectual Capital Measurement in Indonesia," Inference Journal (Accredited). Vol 7 No. 1, page 185-206. ISSN: 1978-7332.

Widyaningrum, Linda 2015. The Effect of CAR, NPF, FDR, and OER Toward ROA of Islamic Financing Bank in Indonesia Period January 2009 to May 2014. JESIT. Vol. 2 No. 12. 